\title{
Microbial contamination in the surface water in the Ba Vi National Park, Ha Noi
}

\author{
Ô nhiễm vi sinh vật trong môi truờng nước mặt Vườn Quốc gia Ba Vì, Hà Nội \\ Research article
}

Le, Nhu Da ${ }^{1}$; Phung, Thi Xuan Binh ${ }^{2}$; and Le, Thi Phuong Quynh ${ }^{1 *}$

${ }^{I}$ Institute of Natural Product Chemistry, Vietnam Academy of Science and Technology, 18 Hoang Quoc Viet, Cau Giay, Ha Noi, Vietnam; ${ }^{2}$ Electric Power University, 235 Hoang Quoc Viet, Bac Tu Liem, Ha Noi, Vietnam

\begin{abstract}
Ba Vi National Park, one of 28 Vietnam National parks, is currently preserved and exploited for a variety of purposes, including the preservation of intact natural forest ecosystems and genetic resources of rare plants and animals. This paper presents the monitoring results of microbial contamination in surface water environment of the Ba Vi National Park (Ha Noi) in the period 2013-2014 and 2018. The results showed that total coliform (TC) density varied from 23 to 11,000 MPN/100ml in bimonthly observation in 2013-2014 which was lower than that one of sampling campaign in 2018, from $900 \mathrm{MPN} / 100 \mathrm{ml}$ to $8,100 \mathrm{MPN} / \mathrm{ml}$. Fecal coliform (FC) densities vaired from 0 to $110 \mathrm{MPN} / 100 \mathrm{ml}$ in $2013-2014$ were lower than that in 2018 , from $0 \mathrm{MPN} / 100 \mathrm{ml}$ to 600 MPN/100ml. At several observation time, both TC and FC were higher than the allowable values of the Vietnam national technical regulation QCVN 08-MT: 2015/BTNMT column A1 for surface water quality. The exceeded values of TC and FC than the allowable values and the increase trend from the 2013 to 2018 periods indicated the potential risks to the public health in this region when people use water for domestic and agricultural purposes. Our results provide dataset for environmental management in the Ba Vi National Park in order to protect the eco-environment in parallel with economical-social development.
\end{abstract}

Vươn Quốc gia Ba Vi, một trong 28 vuờn quốc gia của Việt Nam hiện đang được bảo tồn và khai thác cho nhiều muc đích, trong đó có bảo tồn nguyên vẹn các hệ sinh thái rừng tư nhiên, các nguồn gen động, thực vật quý hiếm, các đặc sản rùng và các di tích lịch sủ, cảnh quan tư nhiên trong vùng. Bài báo trình bày kết quả quan trắc, đánh giá mức độ ô nhiếm vi sinh vật trong môi truờng nước mặt tại Vườn Quốc Gia Ba Vì, Hà Nội giai đoạn 2013-2014 và 2018. Kết quả cho thấy mật độ coliform tổng số (TC) biến đổi trong khoảng tù $23-11.000 \mathrm{MPN} / 100 \mathrm{ml}$ trong các đợt quan trắc định kỳ 2 tháng/lần trong hai năm 2013 - 2014 và trong khoảng tù $900-8.100$ MPN/100ml trong một đọt quan trắc năm 2018. Mật độ fecal coliform (FC) biến đổi trong khoảng tù̀ 0 - $110 \mathrm{MPN} / 100 \mathrm{ml}$ năm $2013-2014$ và tù 0 - $600 \mathrm{MPN} / 100 \mathrm{ml}$ vào năm 2018. Vào một số thời điểm quan trắc, mật độ $F C$ và TC vuoọt giá trị cho phép của quy chuẩn kỹ thuật Quốc Gia QCVN 08-MT:2015/BTNMT côt A1 về chất luợng nước mặt. Các giá trị TC và FC vuợt quá giá trị cho phép và xu huớng gia tăng TC và FC tù 2013 -2018 cho thấy nguy co tiềm tàng khi nguời dân sư dụng nguồn nuớc này cho các muc đỉch sinh hoạt và nông nghiệp. Nhu vậy, kết quả của nghiên cứu này nhấn manh nhu cầu giám sát thuờng xuyên chất lương nước và cần thực hiện các giải pháp hiệu quả để xủ lý và quản lý nguồn gây ô nhiễm trong khu vưc nhằm bảo vệ môi truờng sinh thái song song với phát triển kinh tế - xã hội của khu vục.

Keywords: Ba Vi National Park (Ba Vi NTP), fecal coliform (FC), sustainable development, total coliform (TC), water environment

\section{Introduction}

Coliform is an important indicator in assessing the quality of water environment. Because it is easy to be detected and quantified, coliforms are suitable indicator bacteria for assessing the microorganism contamination level in water environment, including drinking, domestic and aquacultural water. Coliform group is widespread in nature, infecting the human body primarily through the 
consumption of contaminated food and water. Almost coliforms are non-pathogenic coliform, but some strains can cause some illness such as diarrhea, dysentery, urinary tract infections, hepatitis, bronchitis, pleurisy ... Some strains can produce foreign toxins, effecting on nerve cells. Escherichia coli (E. coli) can cause diarrhea, blood disorders and kidney failure, even lead to death. In the world (mainly especially in developing countries), toxic strain E.coli is responsible for about 2.5 million infant deaths per year (Kosek et al., 2003). Consequently, the study of bacteria, especially coliform (total coliform and fecal coliform) in soil and water environment was carried out in many countries in the world (Mendes et al., 2012; Dias et al., 2010; Sá et al., 2014; Nguyen et al., 2014...).

In Vietnam, the TC and FC contamination in some rivers and lakes was observed. For example, TC and/or FC contamination of some urban rivers in Ha Noi (Lich, Lu, Set, Kim Nguu), the Day- Nhue river (ICEM, 2007), the upstream of the Red River (Nguyen et al, 2014), the Red River section flowing through the Hanoi city (Nguyen et al., 2015; 2016) was evaluated.

The $\mathrm{Ba}$ Vi National Park is famous for its rich and variety of fauna and flora. There are many rare animals and plants that need to be protected, preserved and developed (Dang Huy Huynh, 2016). This park is also an important ecotourism point in North Vietnam. However, along with the development of ecotourism, there is a deterioration in the environmental quality in the $\mathrm{Ba} \mathrm{Vi}$ National Park, especially for the surface water environment (Bui, 2012). Limitted information on the water environment quality, especially on microbial contamination in the $\mathrm{Ba} \mathrm{Vi} \mathrm{Na-}$ tional Park was published (Bui, 2012).

In this study, we presented the observation results of microbial contamination in surface water of the $\mathrm{Ba} \mathrm{Vi} \mathrm{Na}-$ tional Park, Ha Noi in the period 2013-2014 and 2018. The results may help for environmental management of the Ba Vi National Park.

\section{Methodology}

\subsection{Study site description}

Ba Vi National Park is located in Ba Vi district (Ha Noi) and Luong Son, Ky Son district (Hoa Binh province) with a total area of 10,815 ha; $50 \mathrm{~km}$ far from Ha Noi center, toward the West. The core zone includes a strict protection zone (2,069 ha), an ecological rehabilitation zone and an administrative and service area (8,714 ha) whereas the buffer zone covers more than 35,000 ha in 16 mountainous communes.

The rainy season lasts from April to October and the dry season occurs from November to next March. Higher temperature and rainfall was observed in rainy season $\left(23^{\circ} \mathrm{C}\right.$ and $100 \mathrm{~mm}$ respectively) than in dry season $\left(20^{\circ} \mathrm{C}\right.$ and 15.0 đến $64.4 \mathrm{~mm}$ respectively) (People's Committee of Ba Vi district, 2014). The Da River (one main tributary of the Red River) and some small artificial reservoirs/lakes such as Suoi Hai lake, Dong Mo lake ... are responsible for water storage and regular water supply for production and for the local human demand in buffer zone (Ba Vi NTP, 2009).

Surface water in the $\mathrm{Ba} \mathrm{Vi}$ has been used for different purposes such as domestic and agricultural activity (Pham Thi Tram, 2015; Nguyen Manh Hung, 2014).

There are no inhabitants in the forbidden forest of the Ba Vi National Park, but the population was relatively high in the buffer zone $(89,928$ inhabitants in 2008) and rapidly increased in the period 2013 - 2017 (Hanoi statistic Yearbook, 2017). Tourism activities are developing strongly with many tourist destinations, attracting approximately 80 thousand visitors per year in the period before 2010 (Bui, 2012). However, the numbers of tourist have been increased rapidly from 139,610 passengers in 2013 to 347,437 passengers in 2016 (Center for Ecotourism and Environmental Education of the Ba Vi National Park, 2017).

The main land occupation is agriculture (wet rice and cash crops, afforestation and fruit trees) in this area. Livestock is the second important agricultural production in this area. According to the Hanoi Statistical Office (2017), livestock in 2015 at $\mathrm{Ba} \mathrm{Vi}$ were 34,520 cattles (buffaloes, cows); 181,112 pigs and 2,209 poultries and an increase trend was observed during the study period.

\subsection{Method}

Table 1: Sampling sites for observation of water quality in the Ba Vi National Park

\begin{tabular}{cccc}
\hline No & Site name & Site position & Site description \\
\hline 1 & NR1 & $\begin{array}{c}21^{\circ} 04^{\prime} 48.7 " \mathrm{~N} \\
105^{\circ} 22^{\prime} 10.8^{\prime \prime} \mathrm{E}\end{array}$ & $\begin{array}{c}\text { Small stream in } \\
\text { forest, core zone }\end{array}$ \\
\hline 2 & $\mathrm{NR} 2$ & $\begin{array}{c}21^{\circ} 04^{\prime} 30.7^{\prime \prime} \mathrm{N} \\
105^{\circ} 21^{\prime} 53.3^{\prime \prime} \mathrm{E}\end{array}$ & $\begin{array}{c}\text { Small stream in } \\
\text { forest, core zone }\end{array}$ \\
\hline 3 & $\mathrm{NR} 3$ & $\begin{array}{c}21^{\circ} 04^{\prime} 08.2^{\prime \prime} \mathrm{N} \\
105^{\circ} 22^{\prime} 55.7^{\prime \prime} \mathrm{E}\end{array}$ & $\begin{array}{c}\text { Tien Stream, } \\
\text { buffer zone }\end{array}$ \\
\hline 4 & $\mathrm{NR} 4$ & $\begin{array}{c}21^{\circ} 06^{\prime} 08.2^{\prime \prime} \mathrm{N} \\
105^{\circ} 22^{\prime} 55.7^{\prime \prime} \mathrm{E}\end{array}$ & $\begin{array}{c}\text { Small stream } \\
\text { near communs } \\
\text { buffer zone }\end{array}$ \\
\hline 5 & $\mathrm{NR} 5$ & $\begin{array}{c}21^{\circ} 05^{\prime} 15.1 " \mathrm{~N} \\
105^{\circ} 23^{\prime} 20.4^{\prime \prime} \mathrm{E}\end{array}$ & $\begin{array}{c}\text { Tien Sa Lake } \\
\text { buffer zone }\end{array}$ \\
\hline 6 & $\mathrm{NR} 6$ & $\begin{array}{c}21^{\circ} 05^{\prime} 39.1 " \mathrm{~N} \\
105^{\circ} 23^{\prime} 22.3^{\prime \prime} \mathrm{E}\end{array}$ & $\begin{array}{c}\text { Vua Pond, buff- } \\
\text { er zone }\end{array}$ \\
\hline
\end{tabular}

Sampling campaigns: Water samples were bimonthly taken during the period from August 2013 to July 2014 and one sampling campaign in March 2018 at six sites located in the Ba Vi National Park region (Table 1 and Figure 1). The samples were taken by the Vietnam Standard method TCVN 6663-6: 2008.

Sample preservation: Water samples were preserved by the Vietnam Standard method TCVN 5993: 1995.

Coliform determination: Total coliforms (TC) and fecal coliform (FC) densities are determined by the most probable number method according to the Vietnamese standard TCVN 6187-2: 1996 which is presented in detail in (Nguyen et al., 2014). 


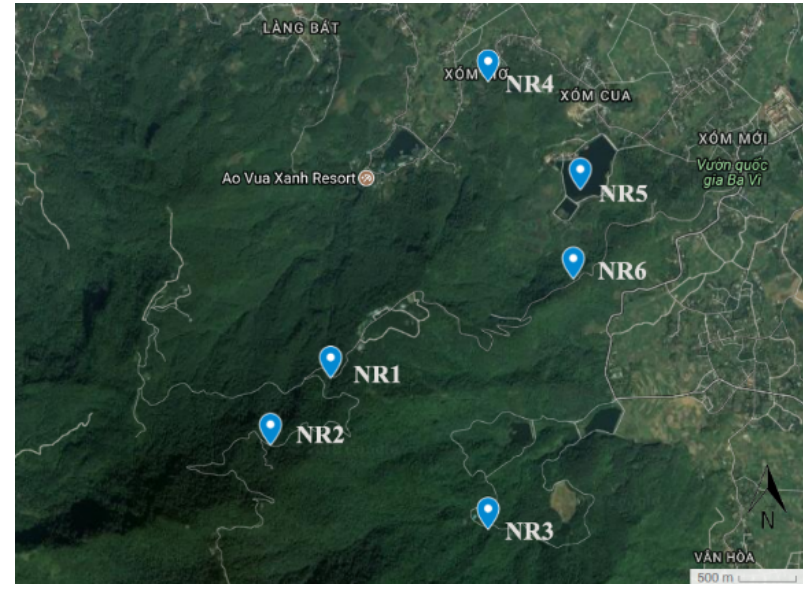

Figure 1. Map of sampling sites

\section{Results and discussion}

\subsection{Total coliform (TC) and fecal coliform (FC) in water environment of the Ba Vi National Park}

The results showed that TC density varied widely, from 23 to $110,000 \mathrm{MPN} / 100 \mathrm{ml}$ in 2013-2014 and from 900 to $8,100 \mathrm{MPN} / 100 \mathrm{ml}$ in 2018 . FC density ranged from 0 to $110 \mathrm{MPN} / 100 \mathrm{ml}$ in 2013-2014 and from 0 to 600 MPN/100ml in 2018 (Table 2).

The median values of TC density of 6 sites in 2013-2014 (67 MPN/100ml) was within the allowable values of the Vietnam national technical regulation QCVN 08MT:2015/BTNMT column A1 (2,500 MPN/100 ml) but the one in $2018(4,050 \mathrm{MPN} / 100 \mathrm{ml})$ was 1.6 times higher than the allowable value. However, during the period 2013-2014, many values of TC and FC at some sites increased dramatically. Notably, very high values, up to $11,000 \mathrm{MPN} / 100 \mathrm{ml}$ were observed at NR2 in April and June 2014 and at NR6 in June 2014. For the sampling campaign in 2018, the TC values at almost sites (NR1, NR4, NR5 and NR6) exceeded from 1.3 to 2.3 times higher than the permissible limits.

Similary to TC density, the median values of FC density of 6 sites in 2013-2014 (4 MPN/100ml) and 2018 (50 MPN/100ml) were within and 2.5 times higher than the allowable values of the Vietnam national technical regulation QCVN 08-MT:2015/BTNMT column A1 (50 MPN/100 ml). However, at several time observed, FC reached to a high value, e.g. at the NR1 site (100 $\mathrm{MPN} / 100 \mathrm{ml})$, at NR2 site $(300 \mathrm{MPN} / 100 \mathrm{ml})$ in July 2014 and in March 2018 and at NR5 site (600 MPN/100 $\mathrm{ml})$ in March 2018.

The TC and FC densities at some time exceeded the allowable values, indicating the potential risks to the public health in this region when people use water for domestic and agricultural activity purposes (Pham Thi Tram, 2015; Nguyen Manh Hung, 2014). Due to the possibility of its pathogens and the spread of infection such as intestinal diseases, urinary tract infections, hepatitis, bronchitis....by harmful coliform group presented in water, effec- tive sollutions should be applied for ameliorating water environment of this area.

Table 2. TC and FC (100 MPN/100ml) in surface water of the Ba Vi National Park

\begin{tabular}{|c|c|c|c|c|}
\hline \multirow[t]{2}{*}{$\begin{array}{c}\text { Sam- } \\
\text { ple } \\
\text { Name }\end{array}$} & \multicolumn{2}{|c|}{$\begin{array}{c}\text { TC } \\
\text { Median } \\
\text { Min } \div \text { Max }\end{array}$} & \multicolumn{2}{|c|}{$\begin{array}{c}\text { FC } \\
\text { Median } \\
\text { Min } \div \text { Max }\end{array}$} \\
\hline & 2013-2014 & 2018 & 2013-2014 & 2018 \\
\hline NR1 & $\begin{array}{c}93 \\
(23-430)\end{array}$ & 8,100 & $\begin{array}{c}0 \\
(0-36)\end{array}$ & 100 \\
\hline NR2 & $\begin{array}{c}75 \\
(23-11,000)\end{array}$ & 900 & $\begin{array}{c}4 \\
(0-10)\end{array}$ & 300 \\
\hline NR3 & $\begin{array}{c}46 \\
(43-230)\end{array}$ & 1,500 & $\begin{array}{c}0 \\
(0-23)\end{array}$ & 0 \\
\hline NR4 & $\begin{array}{c}58 \\
(23-11,000)\end{array}$ & 3,300 & $\begin{array}{c}4 \\
(0-110)\end{array}$ & 0 \\
\hline NR5 & $\begin{array}{c}38 \\
(36-93)\end{array}$ & 5,800 & $\begin{array}{c}4 \\
(0-43)\end{array}$ & 600 \\
\hline NR6 & $\begin{array}{c}75 \\
(63-93)\end{array}$ & 4,800 & $\begin{array}{c}36 \\
(0-63)\end{array}$ & 0 \\
\hline All 6 & 67 & 4,050 & 4 & 50 \\
\hline sites & $38 \div 93$ & $900 \div 8,100$ & $0 \div 36$ & $0 \div 600$ \\
\hline QCV & A $1: 2$ & 00 & A1: & \\
\hline N 08- & A2: 5 & 00 & A2: & \\
\hline MT: & B1: 7 & 00 & B1: & \\
\hline 2015 & B2: 1 & 000 & B2: & \\
\hline
\end{tabular}

Note: QCVN 08-MT: 2015/BTNMT column A1 - Used for domestic water supply (after normal treatment), aquatic animal and plant conservation and other purposes such as A2, B1 and B2; A2 - Used for domestic water supply but suitable treatment technology or use purposes such as B1 and B2; B1-For irrigation or other uses with similar water quality requirements or uses such as B2; B2- Navigation and other purposes with low quality water requirements.

In this study, the TC density of 6 sites in 2013-2014 varied in very large range, from 23 to $110,000 \mathrm{MPN} / 100 \mathrm{ml}$, with a median of $67 \mathrm{MPN} / 100 \mathrm{ml}$. Even very high values at some time were observed in the Ba Vi National Park, the median value was close with that of some lakes and streams in the world such as Kodaikanal and Yercaud tourist lakes in India (Rajakuman et al., 2006) (Table 3). However, much higher TC value in one sampling campaign in March 2018 was closed with that of the surface water in the Cat Ba National Park (Ngo, 2015), in the mangrove ecosystems of the Xuan Thuy National Park (Nguyen et al., 2008). These values were however, much still lower than the values of some urban rivers e.g, the To Lich River, Nhue River, Lu River and Cam River (Hai Phong) (Nguyen et al., 2014), where the domestic wastewater is the main cause of pollution.

Similar trend of FC densities in the water environment of the $\mathrm{Ba} \mathrm{Vi}$ National Park which ranged from 0 to 110 MPN/100 $\mathrm{ml}$ during the whole period 2013 and 2018, with a median value of $4 \mathrm{MPN} / 100 \mathrm{ml}$. The median value was far lower than the FC values of the Red River (Nguyen et al., 2014); the Pichhola lake, India (Dangi et al., 2017); the Kengeri lake, India (Latha et al., 2013); and in the surface water at livestock grazing region in Stanislaus National Forest, USA (CSERC, 2018). However, this value was close with the FC densities at the two Koda- 
ikanal and Yercaud tourist lakes in Tamilnadu province, India (Rajakuman et al., 2006) (Table 3).

Table 3. TC and FC densitites (MPN/100ml) in surface water in the World

\begin{tabular}{|c|c|c|c|}
\hline Location & $\begin{array}{c}\text { TC } \\
\text { Average } \\
\text { Min } \div \text { Max }\end{array}$ & $\begin{array}{c}F C \\
\text { Average } \\
\text { Min } \div \text { Max }\end{array}$ & Reference \\
\hline $\mathrm{Ba} \mathrm{Be} \mathrm{NTP}^{(\mathrm{a})}$ & $\begin{array}{c}650,470, \\
586,430\end{array}$ & - & $\begin{array}{c}\text { Nguyen et al., } \\
2015\end{array}$ \\
\hline $\begin{array}{l}\text { Cat Ba tourist } \\
\text { area }\end{array}$ & 1,200 & - & Ngo, 2015 \\
\hline $\begin{array}{l}\text { Xuan Thuy } \\
\text { NTP }\end{array}$ & 2,254 & - & $\begin{array}{c}\text { Nguyen et } \\
\text { al., } 2008 \\
\end{array}$ \\
\hline Red River & $\begin{array}{c}1,765 \\
23 \div 11,000\end{array}$ & $\begin{array}{c}191 \\
0-1,600 \\
\end{array}$ & $\begin{array}{c}\text { Nguyen et } \\
\text { al., } 2014 \\
\end{array}$ \\
\hline $\begin{array}{l}\text { To Lich Riv- } \\
\text { er }^{(b)}\end{array}$ & $\begin{array}{c}570.10^{3} \\
24.10^{6} \\
\end{array}$ & . & $\begin{array}{l}\text { Nguyen et } \\
\text { al., } 2014\end{array}$ \\
\hline Nhue River & $\begin{array}{c}106,600 \\
\text { (at Thanh Tri) }\end{array}$ & - & $\begin{array}{l}\text { Nguyen et } \\
\text { al., } 2014\end{array}$ \\
\hline Lu River & $160.10^{3}$ & - & $\begin{array}{l}\text { Nguyen et } \\
\text { al., } 2014\end{array}$ \\
\hline $\begin{array}{l}\text { Cam River } \\
\text { (Hai Phong } \\
\text { province) }\end{array}$ & $405-24.10^{3}$ & $310-19.10^{3}$ & $\begin{array}{l}\text { Nguyen et } \\
\text { al., } 2014\end{array}$ \\
\hline $\begin{array}{l}99 \text { Florida } \\
\text { Lakes (USA) }\end{array}$ & $\begin{array}{c}1,670 \\
251 \div 5025\end{array}$ & - & $\begin{array}{c}\text { Hoyer et al., } \\
2006\end{array}$ \\
\hline $\begin{array}{l}\text { Kengeri lake } \\
\text { (India) }\end{array}$ & $\begin{array}{l}640 \text { (Sept) } \div \\
1,500 \text { (May) }\end{array}$ & $\begin{array}{l}210 \text { (April) } \\
\div 510 \text { (July) }\end{array}$ & $\begin{array}{c}\text { Latha et al., } \\
2013\end{array}$ \\
\hline $\begin{array}{l}\text { Pichhola lake } \\
\text { (India) }\end{array}$ & 1,959 & 129 & $\begin{array}{c}\text { Dangi et al., } \\
2017\end{array}$ \\
\hline $\begin{array}{l}\text { Kodaikanal } \\
\text { Lake (India) }\end{array}$ & $\begin{array}{l}46 \div 50^{(\mathrm{c})} \\
46 \div 60^{(\mathrm{d})} \\
33 \div 40^{(\mathrm{e})}\end{array}$ & $\begin{array}{l}27 \div 33^{(\mathrm{c})} \\
33 \div 46^{(\mathrm{d})} \\
17 \div 27^{(\mathrm{e})}\end{array}$ & $\begin{array}{l}\text { Rajakuman } \\
\text { et al., } 2006\end{array}$ \\
\hline $\begin{array}{l}\text { Yercaud Lake } \\
\text { (India) }\end{array}$ & $\begin{array}{c}94 \div 140^{(\mathrm{c})} \\
110 \div 180^{(\mathrm{d})} \\
79 \div 110^{(\mathrm{e})}\end{array}$ & $\begin{array}{c}63 \div 94^{(\mathrm{c})} \\
70 \div 110^{(\mathrm{d})} \\
63 \div 79^{(\mathrm{e})}\end{array}$ & $\begin{array}{l}\text { Rajakuman } \\
\text { et al., } 2006\end{array}$ \\
\hline $\begin{array}{l}\text { Stanislaus } \\
\text { National Forest } \\
\text { (USA) }\end{array}$ & - & $\begin{aligned} & 900^{(f)} \\
> & 1,600^{(g)}\end{aligned}$ & $\begin{array}{l}\text { CSERC, } \\
2018\end{array}$ \\
\hline \multicolumn{4}{|c|}{$\begin{array}{l}\text { Note: }{ }^{(a)} \text { in stream, Ba Be lake } 1,2 \text { and } 3 ;^{(b)} \text { at Thanh Liet } \\
\text { dam and To pond; }{ }^{(c)} \text { summer; }{ }^{(d)} \text { monsoon, }{ }^{(e)} \text { winter, }{ }^{(f)} \text { at } \\
\text { Herring, Jordan, Niagara and Rose Creek, }{ }^{(g)} \text { at Bell, } \\
\text { Herring, and Rose Creek. }\end{array}$} \\
\hline
\end{tabular}

\subsection{Factors affecting on TC and FC densities}

As known, many environmental factors such as temperature, $\mathrm{pH}$, nutrient contents, turbidity, salinity, hydrology and climate could control TC and FC presence in the water environment. In addition, TC and FC densities are directly affected by a wide range of human activities, such as domestic and industrial wastewater (point sources) and runoff from agricultural land... (non-point sources).

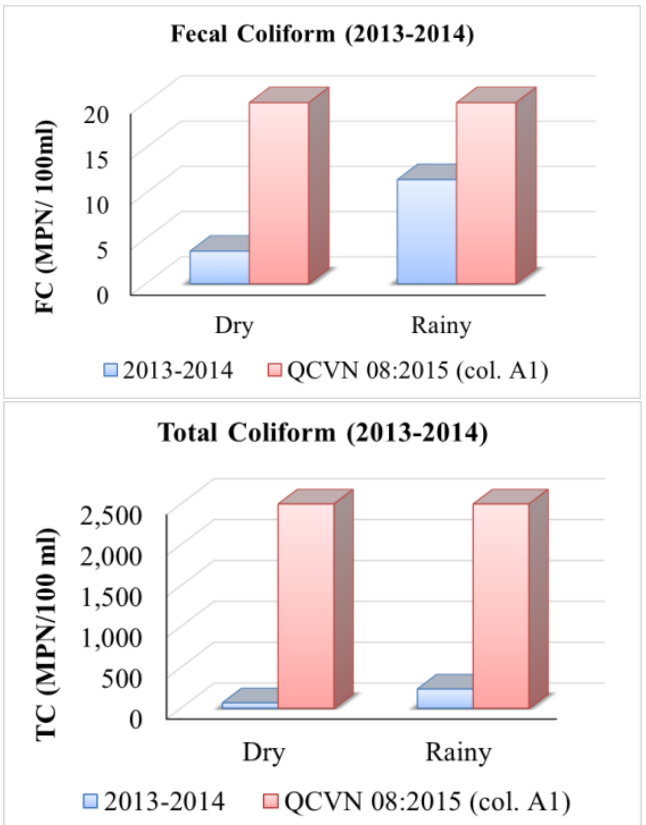

Figure 2. Median value of TC and FC in water surface of 6 sites of the Ba Vi National Park in dry and wet seasons during the period 2013-2014

Figure 2 shows the median values of TC and FC densities in dry (in the range $23-8,100 \mathrm{MPN} / 100 \mathrm{ml}$; FC: $0-10$ $\mathrm{MPN} / 100 \mathrm{ml}$ ) and wet seasons (in the range TC: 23 11,000 MPN/100ml; FC: $0-600 \mathrm{MPN} / 100 \mathrm{ml}$ ) in the period 2013-2014. The results show that the median TC and FC densities in the rainy season were 3.5 and 3.0 times higher than the ones in the dry season. The study of (Rajakuman et al., 2006) also showed the difference between the TC and FC densities in rainy (summer) season compared to dry season (winter) in the Kodaikanal and Yercaud tourist lakes in Tamilnadu, India (Table 3). Higher values of TC from $402 \div 46,110 \mathrm{MPN} / 100 \mathrm{ml}$ in the rainy (summer) season than in the dry (winter) season $103 \div 4,920 \mathrm{MPN} / 100 \mathrm{ml}$, were also observed for the Xuan Thuy National Park in Vietnam (Haneji, 2014).

Land cover is an important factor in controlling TC and FC values. The study for the Seine river basin (France) showed that the FC in streams which flow through grassland grazing (FC: 1,000 MPN/100 ml) was much higher than the ones in streams flowing through the forest land and the cultivable land (FC: $100 \mathrm{MPN} / 100 \mathrm{ml}$ ) (Servais et al., 2007). These authors demonstrated that there was no significant difference between the average FC densities in streams which flow through forest land and cultivable land.

When comparing the values of TC and FC in March 2014 and 2018 (Figure 3), much higher values in 2018 (4,050 and $50 \mathrm{MPN} / 100 \mathrm{ml}$ respectively) were found than the ones in in the period 2013-2014 (68 and 0 MPN/100 ml respectively). 


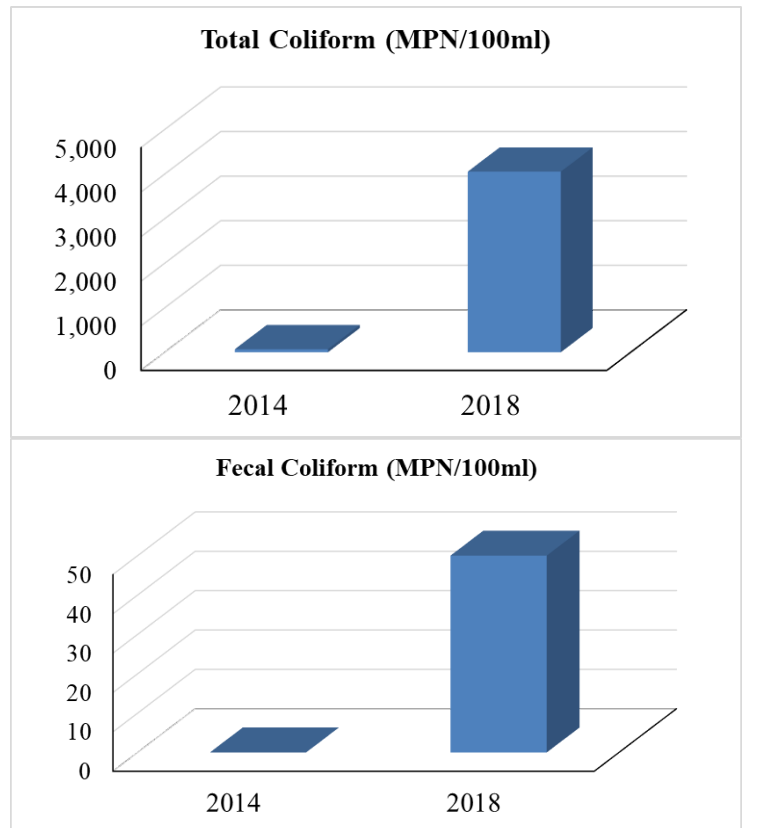

Figure 3. Median values of TC and FC densities in water surface of 6 sites in the Ba Vi NTP in March 2014 and March 2018 (dry season)

As known, FC is only presented in human and animal warm-blooded feces, the presence of FC in water environment indicates the human and animal (including warm-blooded wildlife) faecal inputs to natural waters in this region. Thus, the increased FC densities in water environment in March 2018 compared to March 2014 indicate the increase of human and animal warm-blooded feces toward water effluent (streams and lakes) in the Ba Vi National Park. As presented above, from the year 2013 to 2018 , rapid changes in the economic and social conditions in this region were observed. The numbers of tourist increased three times from 2013 to 2016 (Center for Ecotourism and Environmental Education of the $\mathrm{Ba} \mathrm{Vi} \mathrm{Na}-$ tional Park, 2017). In this period, inhabitants and livestocks in the buffer zone have clearly increased (Hanoi Statistical Office, 2017). However, no information concerning wastewater collection or treatment for this area exists. We suggested that the increase of different point sources and non-point sources probably gave favorit for the increase of coliform during our study period. Our study emphrasises effective measures should be taken to treat and prevent the polluted sources in this area.

\section{Conclusions}

Total coliform and fecal coliform densities were observed in the water environment of the $\mathrm{Ba} \mathrm{Vi}$ National Park in the periods 2013-2014 and 2018. The results showed that TC density varied widely, from 23 to $110,000 \mathrm{MPN} / 100$ $\mathrm{ml}$ in 2013-2014 and from 900 to $8,100 \mathrm{MPN} / 100 \mathrm{ml}$ in 2018. FC density ranged from 0 to $110 \mathrm{MPN} / 100 \mathrm{ml}$ in 2013-2014 and from 0 to $600 \mathrm{MPN} / 100 \mathrm{ml}$ in 2018. Notably at some time observed, both $\mathrm{TC}$ and $\mathrm{FC}$ values were much higher than than allowable values of the Vietnam national technical regulation QCVN 08-MT: 2015/BTNMT column A1.
The seasonal variation of both TC and FC was observed, probably due to higher temperature in rainy season than in dry season. The increase of TC and FC was found when comparing the values in March 2014 and March 2018. The median values of TC and FC during the period 20132014 were within the allowable values whereas both median TC and FC dendsities in 2018 were 1.6 and 2.5 times respectively higher than the allowable values. The increase trend of TC and FC in 2018 vs. 2013-2014 may reflect the increase of point and non-point sources in this region.

The TC and FC exceeded the allowable values, are the potential risk to public health in this area, especially when water in stream/lakes is used for agricultural activities. Thus, our results emphasizes the need for regular monitoring of water quality as well as for implementing effective solutions to treat and manage pollution sources in the area in order to protect the eco-environment and in parallel with economical-social development of the $\mathrm{Ba} \mathrm{Vi}$ National Park region.

Acknowledgements: The authors would like to thank the Institute of Natural Product Chemistry (INPC, VAST) and the Vietnam's National Foundation for Science and Technology Development (NAFOSTED-Vietnam) (105.092012.10 project) for their financial support.

\section{References}

[1] Ba Vi National Park (2009) Report on the project "Conservation and development planning of $\mathrm{Ba} \mathrm{Vi}$ National Park for the period 2009-2020" (in Vietnamese).

[2] Bui T. N. M. (2012) Solution for Suitainable EcoTourism development at Ba Vi National Park, Journal of Foresty Science and Technology, 1, 148-169 (in Vietnamese).

[3] CSERC (2018) Central Sierra Environmental Resource Center, Water Quality Monitoring of Surface Waters in the Stanislaus National Forest - 2017, Annual Report Ninth Year of Study.

[4] Center for Ecotourism and Environmental Education of the Ba Vi National Park (2017), Business performance Report for the years 2013, 2014, 2015 and 2016 (In Vietnamese).

[5] Dang Huy Huynh (2016) The need of conservation and sustainable use of the Ba Vi National Park - the unique natural heritage of Hanoi, Environmental Journal, 3, 28-30 (In Vietnamese).

[6] Dangi P. L., Sharma B.K. and Uppadhyay B. (2017) BOD, Total and Faecal coliforms bacterial status of Lake Pichhola, Udaipur, Rajasthan, International Journal of Fisheries and Aquatic Studies, 5(3), 176180.

[7] Dias A.C.F., Andreote F.D., Rigonato J., Fiore M.F., Melo I.S., and Araújo W.L. (2010) The bacterial diversity in a Brazilian non-disturbed mangrove sediment, Antonie Van Leeuwenhoek, 98, 541-551.

[8] Haneji C. (2014) Research on Development of Bio- 
diversity Indicators for Mangrove Ecosystem of Xuan Thuy National Park, Vietnam. Doctoral Dissertation. Graduate School of Environment and Information Science Yokohama National University.

[9] Hanoi Statistical Office (2017), Statistical Yearbook 2016, (In Vietnamese).

[10] Hoyer M.V., Donze J.L., Schulz E.J., Willis D.J, and Canfield Daniel E.Jr. (2006) Total Coliform and Escherichia Coli Counts in 99 Florida Lakes with Relations to Some Common Limnological Factors, Lake and Reservoir Management, 22(2), 141-150.

[11] Kosek M., Bern C., and Guerrant R. L. (2003) The global burden of diarrhoeal disease, as estimated from studies published between 1992 and 2000 . Bull. W. H. O. 81, 197-204.

[12] Latha N. and Mohan M. R. (2013) Microbial pollution- total coliform and fecal coliform of Kengeri lake, Bangalore region Karnataka, India, International Journal of Scientific and Research Publications, 3(11), 1-3.

[13] Mendes L.W., Taketani R.G., Navarrete A.A., and Tsai S.M. (2012) Shifts in phylogenetic diversity of archaeal communities in mangrove sediments at different sites and depths in southeastern Brazil, Res. Microbiol, 163, 366-377.

[14] Ngo T. H. (2015) Assessment of the environmental management efficiency on Cat Ba National Park, Master of Science Thesis, Hanoi University of Science, Vietnam National University, Hanoi (In Vietnamese)

[15] Nguyen T. B. N., Nguyen B. T., Nguyen T. M. H., Vu D. A., Duong T. T., Ho T. C., Le T. P. Q. (2014) Preliminary monitoring results of Total Coliforms and Fecal Coliform in the Red River system, in the section from Yen Bai to Hanoi, Journal of Biology Vietnam Academy of Science and Technology, 36(2), 240-246 (In Vietnamese).

[16] Nguyen Manh Hung (2014) Applying the tourism cost method for assessing the landscape value of $\mathrm{Ba}$ Vi National Park, Master thesis, Thuy loi University, 91 pages.

[17] Nguyen T. H. N., and Le T. N. (2008) Current situation assessment of water quality of irrigation system in Giao Thuy district, Nam Dinh Province, Journal of Wate Resources and Environmental Engineering, 20, 60-65 (In Vietnamese).

[18] Nguyen T. M. H., Le T. P. Q., Phung T. X. B., Rochell-Newall, E. Janeau, J. L. Garnier, J. Billen G.
(2015) Relationship between bacteria and environmental factors in the Red River section from Hanoi to Hung Yen. Journal of Science and Technology, Hanoi University of Industry, 28, 61-65 (In Vietnamese).

[19] Nguyen T. M. H., Le T. P. Q., Garnier J., Janeau JL. J., and Rochelle-Newall E. (2016) Seasonal variability of faecal indicator bacteria numbers and die-off rates in the Red River basin, North Viet Nam, Scientific Reports 6, 21644, DOI: 10.1038/srep21644.

[20] Nguyen Q. T., H. T. T. H., and Hoang V. H. (2015) Research areas sensitive to the environment in $\mathrm{Ba} \mathrm{Be}$ district, Bac Kan province, Proceedings of the 6th National Sciencific Conference on Ecology and Biological Resources, Hanoi, 10, 1686-1692 (In Vietnamese).

[21] Nguyen V. H. (2017) Study on some establishments paying forest environmental services in the field of tourism business in the Ba Vi National Park, Graduated thesis, Hanoi University of Natural Resources and Environment (In Vietnamese).

[22] People's Committee of Ba Vi district, Ha Noi city (2014) General introduction about the Ba Vi district, Ha Noi city. Portal at http://bavi.hanoi.gov.vn/gioithieu (In Vietnamese).

[23] Pham Thi Tram (2015) Set up geographic basis for sustainable development in Son Tay area - Ba Vi in the process of urbanization of Hanoi, $\mathrm{PhD}$ thesis, Hanoi National University, University of Natural Science, 206 pages. (In Vietnamese).

[24] Rajakumar S., Velmurugan P., Shanthi K., Ayyasamy P.M. and Samy L. P. (2006) Prevalence of Coliform Bacteria in Kodaikanal and Yercaud Lake, Tamilnadu, South India, Research Journal of Microbiology 1(6), 527-533.

[25] Sá A.L.B., Dias A.C.F., Qecine M.C., Cotta S.R., Fasanella C.C., Andreote F.D., and Melo I.S. (2014) Screening of endoglucanase-producing bacteria in the saline rhizosphere of Rhizophora mangle, Braz. J. Microbiol, 45, 193-197.

[26] Servais P., Garcia-Armisen T., George I., and Billen G. (2007) Fecal bacteria in the rivers of the Seine drainage network (France): Sources, fate and modeling. Sci. Total. Environ., 375, 152-167.

[27] Servais P., Billen G., Goncalves A., Garcia-Armisen T. (2007) Modelling microbiological water quality in the Seine river drainage network: past, present and future situations. Hydrol. Earth Syst. Sci., 11, 15811592. DOI:10.5194/hess-11-1581-2007. 